\title{
LAPURDUTI
}

Euskal ikerketen aldizkaria | Revue d'études basques |

Revista de estudios vascos | Basque studies review

$13 \mid 2009$

Numéro XIII

\section{Aldaketak Prosodiaren Esparruan : Ikergaiak eta arazo metodologikoak}

Iñaki Gaminde, Jasone Salaberria et Ander Olalde

\section{OpenEdition}

\section{Journals}

Édition électronique

URL : http://journals.openedition.org/lapurdum/2068

DOI : 10.4000/lapurdum.2068

ISSN : 1965-0655

Éditeur

IKER

Édition imprimée

Date de publication : 1 février 2009

Pagination : 189-199

ISBN : 978-2-86781-409-X

ISSN : $1273-3830$

Référence électronique

Iñaki Gaminde, Jasone Salaberria eta Ander Olalde, « Aldaketak Prosodiaren Esparruan : Ikergaiak eta arazo metodologikoak », Lapurdum [Linean], 13 | 2009, Sarean emana----an 15 avril 2013, kontsultatu 19 avril 2019. URL : http://journals.openedition.org/lapurdum/2068 ; DOI : 10.4000/lapurdum.2068 


\title{
Aldaketak Prosodiaren Esparruan: Ikergaiak eta arazo metodologikoak
}

\author{
Iñaki GAMINDE, Jasone SALABERRIA eta Ander OLALDE \\ UPV/EHU-Iker UMR5478
}

\section{Laburpena:}

Komunikazio honen helburua euskararen prosodiaren azterketen egoera aurkeztea da. Alde batetik, ikerketa esparru honen arloen mugapena egin ondoren euskararen azterketen egoera zertan den ikusiko da. Bestetik egin diren ikerketa batzuetako esperientzian oinarrituta aurkitu diren arazo metodologikoez jardungo dugu. Azken honetan aldaketa eta aldaeren arazoa bete-betean kokatzen da. Horrekin batera lan eremu hauek lantzeko Euskal Herri osoan abian daukagun proiektu baten berri emango dugu.

Aztertuko diren arloetarik batzuk honako hauek izango dira: Prosodiaren arloak, prosodiaren arlo linguistikoa (azentua eta intonazioa), arlo paralinguistikoa (jarrerak), arlo ez linguistikoa (adina, sexua, egoera fisikoa, emozioak), egungo euskaldunekin gogotan erabili behar diren ezaugarriak azterketa eremuan (geografikoak, sozialak, estilistikoak).

\section{Résumé:}

Le but de cette communication est de présenter l'état des recherches sur la prosodie de la langue basque. D'une part, après avoir circonscrit le champ de référence considéré, l'état des recherches en cours sera présenté. D’autre part, on s'intéressera à un certain nombre de problèmes méthodologiques ayant surgi lors de recherches fondées sur l'expérience. Cette dernière question renvoie directement aux aspects de changement et d'évolution. Ces travaux de recherche s'inscriront également dans le cadre d'un projet que nous démarrons actuellement sur l'ensemble du Pays Basque.

Certains des aspects qui seront traités sont les suivants : les champs de la prosodie, les aspects linguistiques de la prosodie (accent et intonation), ses aspects paralinguistiques (attitudes), ses aspects non-linguistiques (âge, sexe, état physique, émotions), les caractéristiques des champs d'in- 
vestigation qui doivent être prises en considération avec les basques d'aujourd'hui (géographiques, sociales, stylistiques).

\section{Abstract:}

The aim of this communication is to present the state of the research related to Basque prosody. On the one hand, after having defined the boundary of our reference field, the state of current researches will be presented. On the other hand, the focus will be put on some methodological issues that have been raised by experience grounded researches. This last question is directly related to change and evolution. These research works will be a part of an integrative project incorporating the whole Basque Country.

The following aspects will be considered: prosody's fields, prosody's linguistic aspects (stress and intonation), paralinguistic aspects (attitudes), non-linguistic aspects (age, sex, physical state, emotions) and the characteristics of the fields of investigation that must be taken into consideration with today's Basque people (geographical, social, stylistic).

Hitz gakoak: Prosodia, hizkuntzaren bariazioa, metodologia, azterketa akustikoa.

Mots clés: Prosodie, la variation de la langue, méthodologie, analyse acoustique.

Key words: Prosody, the variation of the language, methodology, analyzes acoustic.

\section{Sarrera}

Lan honetan Euskal Herri osoan prosodiaren azterketan sakontzeko abaian jarri berri dugun proiektu baten lehen aldiaren helburuak aurkeztu nahi ditugu. Horretarako erabili ditugun hatsarre teorikoak zehaztu eta eztabaidatu ere egingo ditugu hasieran.

Orain artekoan ahozko euskararen gainean egin diren lan gehienetan helburu nagusia bertako berezko ezaugarriak eta berezitasunak gordetzea izan da. Ikertzaile-biltzaile askoren sentimenduan euskararen atzerakako joera sarritan egon da presente eta nahi izan da ahal denik eta euskararik bertakoena eta garbiena gordetzea galdu aurretik. Bestetik, eta dialektologia klasikoak eraginda, jaso diren ezaugarri horiek, gehienez jota, hangoekin eta hemengoekin erkatu dira kasurik onenean. Egon dira eta ugarituz doaz forma bildumekin batera azterketak ere egiten dituzten lanak; era berean, datu horiek baliatuta aplikazioak lortu nahi dituzten bakan batzuk ere hasi dira agertzen.

Edozelan ere, ikuspuntu horretatik lekukoak gehienetan aukeratzen izan dira baldintza zehatz batzuen arabera: pertsona nagusiak, herrian bertan jaioak, gurasoak bertakoak eduki dituztenak, bertatik mugitu ez direnak, euskaraz analfabetoak, e.a. Era horretako lekukoak bizimodu eta gizarte harreman batzuekin lotuta egon dira eta daude; nahiz egun azken hau guztiz egia ez izan, izan ere, inguruko mundutik ezin ihes egin dezakete kanpaia baten barruan baleude bezala. Ezin ukatuzkoa da metodologia honek hizkuntzaren gaineko ideologia zehatz batekin lotzen dena, beronen sustraiak XIX. mendeko dialektologia klasikoan topa daitezke. Usu horrela jokatu dugu inertziaz; hau da, arteragokoek hala egin dutelako eta korrontearen abaroak babestu gaituelako; gaur uste dugu badela sasoia hau guztia errebisatzeko eta aurrera Aurrera pausu horiek errealitateak berak eragiten ditu. Non daude jator kutsu hori eman dezaketen lekukoak? Geratzen diren belaunaldi horietako lekukoak ez direnean, ez da ahozko euskararen gaineko azterketarik egingo? Euskal hiztun komunitatean ez da ezer gertatzen, bakartuta gaude?

Argi dago galdera hauei erantzuteko ikuspuntu aldaketa sakona behar dugula. Ez dugu ukatu nahi azterketa klasikoen balioa; euskararen historiarako material interesgarriak bil daitezke, hizkuntzaren gaineko azterketak egiteko datuak ematen dizkigute eta zenbait esparrutan aplikazioak 
garatzeko ere balio diezagukete, beti ere hurrengo urratsari ekiten bazaio eta datu bilduma hutsetan geratzen ez bagara.

Lan honetan, gorago esan dugun moduan, prosodiaren ezaugarriak ikertzeko darabilgun proiektuaren helburuak aurkeztu nahi ditugu. Proiektuaren lehen aldi honetan, Euskal Herrian 178 inkesta egingo dira 18-29 urte arteko emakumezko lekukoekin. Iparraldeari dagokionez lekukoak 22 izango dira. Lanaren hirugarren sekzioan xehetasun gehiagorekin aztertuko ditugu ezaugarri nagusiak. Sekzio horretako aukeraren hatsarre teoriko nagusiak bi izan dira, hizkuntzaren bariazioa eta prosodiaren gainean daukagun ikuspuntua. Hauexek izango dira, orduan, bigarren eta hirugarren sekzioetan aurkeztuko ditugunak hurrenez hurren.

\section{Proiektuaren deskripzioa}

Gure proiektuaren helburua Euskal Herri osoan prosodiaren gaineko arlo batzuk lantzea da. Sarreran aipatu dugun bezala proiektuaren lehen aldian gaude eta beronek murrizketa batzuk eragin ditu lekukoen aukeraketan. Honelako proiektuetan eta oro har ahozko hizkuntzaren gaineko edozein azterketari ekiten zaionean lau aldi nagusi bereiz ditzakegu. Lehena, hemen aurkeztuko duguna, prestakuntza aldia izaten da; aldi honetan helburuak finkatu, aitzinkariak aztertu, inkesta puntuak aukeratu, lekukoen ezaugarriak definitu eta galdekizunak prestatu egiten dira. Gainerako aldiak seinaleak jasotzea, seinaleak erabiltzea eta seinaleak aztertzea izaten dira; aldi hauetan egoten diren arazo teorikoak zein metodologikoak beste baterako utziko ditugu.

Hirugarren sekzioan prosodiaren gainean arituko gara hemen egin dugun aukera justifikatzeko. Aipa ditzagun oraingoz landuko ditugun arloak:

(a) Azentua:

Berba bakartuak eta talde klitikoak

(b) Intonazioa:

Esaldi enuntziatiboak

Bai/ez galderak

N/Z galderak

(c) Emozioak

Poza, tristura, haserrea, beldurra eta harridura

(d) Jarrerak

Ironikoa, abegikorra eta errietaria

(e) Testuak

Bat-bateko testuak: narrazioa eta instrukzioa

Testu irakurria

Euskarazko materialekin batera Hegoaldean gaztelaniazkoak eta Iparraldean frantsesezkoak ere jasoko ditugu erkaketak egin ahal izateko. Erdara bietan jasoko ditugun materialak arean murritzagoak izango dira; goiko zerrenda horretan ondoko era honetara geratzen da:

(b) Intonazioa:

Esaldi enuntziatiboak

Bai/ez galderak

N/Z galderak

(c) Emozioak

Poza, tristura, haserrea, beldurra eta harridura

(d) Jarrerak 
Ironikoa, abegikorra eta errietaria

(e) Testuak

Bat-bateko testuak: narrazioa

Testu irakurria

Bigarren sekzioan eztabaidatuko ditugun arrazoiak direla eta, gure lekukoak hiru motatakoak izango dira:

(A) Barietate klasikoren bat jaso dutenak

(B) Euskara eskolatzean ikasi dutenak

(C) Barietate berria jaso dutenak

A taldeko lekukoak dira euskara txikitan etxean jaso dutenak, elebidunak eta bigarren sekzioan ikusiko ditugun beste ñabardura batzuk egin daitezke hemen. B taldekoak txikitatik euskara eskola giroan jaso dutenak dira, nahiz euretariko askok eskolatik kanpo ez duten erabiltzen. C taldekoak, azkenik, euskara etxean jaso dute baina guraso biak euskaldun berriak eduki dituztenak dira.

Inkesta puntuak aukeratzeko lekuko motak, eskualde banaketa, populazio osoa eta euskaldunen portzentajeak erabili ditugu. Lekuko moten arabera A taldekoak 95 dira, B taldekoak 65 eta C taldekoak 18 (denetara 178). Eskualde euskaldunen kasuan denetara hedatu nahi izan dugu bertako barietate klasikoak islatuta agertzeko.

Aldi honetan lekuko guztiek baldintza zehatz batzuk bete behar dituzte generoaren, adinaren eta ikasketen arabera. Denak andrazkoak dira, 1980-1990 urte bitartekoan jaiokoak, hau da 18-28 urte artekoak, euskal ereduetan (D ereduan Hegoaldean) ikasi dutenak eta unibertsitate ikasleak direnak.

Inkesta puntuak 1. taulan agertzen direnak dira. C taldeko lekukoak ez dira besteak gaina erraz topatzen ingurune geografiko zehatz bati lotuta, arazo metodologiko honegatik eremua herrialdea izatea erabaki dugu: Bizkaian 6 lekuko izango dira, Araban 2, Gipuzkoan 4, Nafarroan 4 eta Lapurdin 2. A eta B taldeetako lekukoak gorago aipatu ditugun irizpideen arabera honela banatzen dira herrialdeka:

\begin{tabular}{|c|c|c|}
\hline Herrialdea & A & B \\
\hline Bizkaia & 40 & 20 \\
\hline Araba & 1 & 14 \\
\hline Gipuzkoa & 27 & 18 \\
\hline Nafarroa Garaia & 12 & 5 \\
\hline Lapurdi & 7 & 0 \\
\hline Nafarroa Beherea & 5 & 0 \\
\hline Zuberoa & 3 & 65 \\
\hline Orotara & 95 & \\
\hline
\end{tabular}

1. Taula: A eta B taldeetako lekukoen banaketa herrialdeka

\section{Hizkuntzaren bariazioaz}

Sekzio honetan proiektuaren lekukoak aukeratzeko erabili ditugun irizpideak nahi genituzke argitu neurri batean besterik ez bada, horretarako hizkuntzaren bariazioaz eta Euskal Herrian azkenaldion izan diren gertaera sozial batzuk gomutan erabiliko ditugu. 
Gauza jakina da hizkuntza guztiak aldatu egiten direna eta aldatzen ez dena galdua dena. Euskararen kasuan ahozkotasunaz egiten diren ikasketetan hatsarre hau ez da gogotan erabiltzen, sarreran esaneko moduan. Halaber, gogotara ekarri beharko genuke hizkuntzaren bariazioa hiru mailatan gertatzen dela: diatopikoan, diastratikoan eta diafasikoan.

Bestalde, euskararen egoera ez da bat bera hizkuntza egiten den eremu osoan; ez legez, ez transmisioari dagokionez, ez hizkuntzaren irakaskuntzaren esparruan, ez eta kasik ezertan ere. Egoeraren konplexutasun horrek zaildu egiten du ikerkuntza bera baina ezin atzera egin dezakegu horregatik, izan ere, euskaldunen eta euskaltzaleen borondateak eraginda bada datu objektibo bat:

Gure aspaldiko historian lehen aldiz euskararen gaineko datuak hizkuntzaren eremu osoan jaso ditzakegu. Hau da Lanestosatik, Kaskanteraino eta Kaskantetik Eskiularaino egiten den edo egin daitekeen bertako euskara azter daiteke, belaunaldi gazteen artean.

Ikertzaile batzuek iradoki duten moduan, aspaldion Iparraldearen eta Hegoaldearen arteko etena areagotu egin da arrazoi franko bitarteko. Ez ditugu hemen arrazoi horiek guztiak aztertuko; batetik, ezagutzen ez ditugulako eta, bestetik, lan honen mugak gaindituko dituztelako. Hala ere, Bizkaiko egoeraren eragile batzuk, ondoen ezagutzen ditugunak, aurkeztuko ditugu.

XXI. mende honetako egoera linguistikoa arean ulertzekotzat XX. mendean gertatu diren hiru aldi nagusien ezaugarriak gogotan erabili beharko genituzke. Aldiok erraz identifika daitezkeen arren ez dira aro garbitzat hartu behar ezpadaze transizio eremutzat. Batetik bestera pasatzean egoerak nahaspilatuta agertzen zaizkigu hizkuntzaren eremu geografikoan. Hala ere, muturretako egoerak erraz identifika daitezke eta erdikoa gure belaunaldiarena litzateke, une historiko zehatz batean eztanda egin zuena eta hemen deskribatu nahi den egoera berria irudikatzeko balio diezagukeena.

Lehen aldian Bizkaian, eta gure jakitatean Euskal Herri osoan gutxi gorabehera, nahiko komunitate linguistiko berezituak egon dira. Alde batetik euskaldunak bizi ziren eta bestetik erdaldunak, egia da ezagutu ditugun kasuak kontuan edukita, zenbaitetan erdaldun batzuk euskaldunen komunitatean integratzen zirena era naturalez; arruntena ostera euskaldunek euren hizkuntza galtzea zen.

Euskararen pizkundearekin batera 70 hamarkadaren amaiera aldean, euskararen irakaskuntza hedatzen hasi zen eta beronekin batera euskara batua ere bai. Aldi honetan euskaldunen komunitatean euskaldun berrien fenomenoa agertu zen indar handiz eta apurka-apurka finkatuz joan den taldea osatu zen. Une batzuetan euskaldun zaharrak eta euskaldun berriak bereizten ziren argiro.

Urteotan euskal komunitate linguistikoaren konplexutasuna handituz joan da eta era guztietako euskaldun motak sortu dira. Bien bitartean hizkuntza eta barietate klasikoak erabiltzeko sareak ez dira sendotu nahi adina. Esan nahi da, euskaldun elebakarrak kasik desagertu direla; batez ere zaharrenak eta ume txiki elebakarrek badakigu berehala ikasten dutena erdara; are gehiago, bizimoduaren aldaketek eraginda inoizko arinen, izan ere, lehen sei urterekin hasten bazen eskolara, hau da hizkuntza nahikoa finkatuta zeukatenean, orain jaio orduko hasten dira, etxeko eredua finkatu baino lehen eta leku askotan murgiltzea erdal ereduetan egiten da, zalantza barik. Bestalde, ezin ahatz dezakegu umeen zaintza gurasoen esku baino, sarri askotan, etxetik kanpoko zaintzaileetan utzi behar izaten dela ezinbestez eta beti ezin topa daitezkeela zaintzaile euskaldunak. Gaurko egoeran gero eta gehiago uzten da euskararen transmisioa hezkuntzaren esparruan. Bestalde, ezin ahaztuzkoa da Bizkaiko eta Euskal Herriko paisaia linguistikoa aldatuz eta ñabartuz doala etengabe, berriki egin den ikerketa baten arabera (Uranga eta lag., 2008), 100tik gora dira gaur Erkidego Autonomoan egiten diren hizkuntzak.

Aurreko guztia gogotan, alde batetik guganaino belaunez belaun transmititu eta heldu diren barietate linguistikoak ditugu, euskararen kasuan euskalkiekin lotuta, jakina. Bestetik, gizarte al- 
dagaien arabera dauden barietate sozialak edo soziolektoak. Eta, azkenik, bariazio diafasikoaren esparruan, erregistroak; arlo honetan kontuan hartu behar da euskaldun gazte askok ikasketak euskaraz egiten dituztela eta euskara batuaren eragin nabarmena daukatela.

Argi dago itxurako anabasa horretan aldaki eta molde desberdin franko aurki dezakeguna. Baina aztertu ezagatik edo kontuan hartu ezak ez du esan nahi ez direnik. Aldaketaren zergatietan sakon sartu gura ezta, eragiten dioten faktore batzuk ekarri gura ditugu bertora, hausnarketarako interesgarriak izango direlakoan.

Berezko bilakaera daukagu oinarrizkoena; berezkotasun horretaz ñabardurak egin behar badira ere, esan dezagun ezen, barietate edo euskalki klasikoez ari garela. Jakina denez, horiek ere aldatzen ari dira gure begien aurrean, aldaketa fonetikoek eta analogikoek eraginda bereziki.

Euskararen esparruan gertatzen ari diren aldaketez egin diren lan batzuk badaude; Aurrekoetxea eta lag.-ek (Aurrekoetxea, 2003, 2004, 2006, 2008 eta Aurrekoetxea eta Ormaetxea, 2006) oinarrizko datuen bilketaz eta azterketez arduratu dira; lan horien emaitzarik nabarmenena Euskara Dialektalaren Ahozko Korpusa (EDAK) proiektua eta Euskal Dialektologia (EUDIA) ikerketa taldea osatu izana dira (EUDIA, 2008). Hualde (2004), aldaketen eragileez teoria linguistikoaren ikuspuntutik arduratu dena eta marko teoriko sendo baten barruan azalpenak eman gura izan dituena; ikertzaile honen eta beronen lagunen azken emaitza ikusgarria Goizuetako euskararen gainean egindako lana da (Hualde, Lujanbio eta Torreira, 2008). Prosodiaren eremuan hainbat dira gurea ez den beste hizkuntzetan egiten diren lanak bariazioa kontuan hartuta (Matín Butragueño, 2002; Enbe. eta Tobin, 2008, askoren artean). Gure kasuan Gaminderen lana (2008) proiektu honen abiapuntutzat jo daiteke.

Lekukoen hizkuntzaren araberako sailkapena egiten badugu, konbinazio asko aurkitzen ditugu. Lekukoak mailakatzeko irizpide nagusi bi erabil ditzakegu: Lehen hizkuntza eta Euskara erabiltzeko aukerak. Lehen hizkuntzatzat jotzen dugu etxean txikitan lehenengoz ikasi dena eta etxeko giroan erabil daitekeena. Honetarako guraso biak euskaldunak izan behar dira, izan ere, eurotariko bat erdalduna izan den kasuetan hasierako erlazio linguistikoetan umearekin hizkuntza erabil daitekeen aukera guztietan \%33an baino ez litzateke erabiliko. Jo dezagun A eta B gurasoetan eurotariko bat erdalduna dela, umearekin egotean hiru aukera daude (AU, BU eta ABU), jakin dakigun moduan, erdalduna dagoen kasu guztietan erdara egingo da, bera elebakarra delako; kasurik onenetan umeari zuzenean berba egikeran euskaldunak euskara erabiliko du, baina argi dago honelako kasu gehienetan umea elebiduna izango dena jatorriz eta ez euskaldun hutsa.

Beraz jatorrizko euskaldunen artean mota desberdinak edukiko genituzke; lehen hizkuntzatzat euskara jaso dutenak eta elebidunak izan direnak. Lehenengoen artean, era berean, beste mota bi dauzkagu, batetik euskararen barietate klasikoren bat jaso dutenak eta, bestetik, euskararen barietate berriren bat jaso dutenak; azken horien artean euskaldun berrien seme-alaba euskaldun zaharrak kokatu beharko genituzke. Lehen aipatu ditugun populazioaren mugimenduek eraginda, beste bereizketa bat egin beharko genuke euskararen barietate klasikoren bat jaso dutenen artean, izan ere, ez da berdin barietate horren jatorrizko inguruan bizi izatea edo beste lekuren baten bizi izatea. Esan nahi da ze, jatorrizko inguruan bizi izan direnak hizkuntzaren inguruneko bilakaeraren parte izan direla eta bilakaera horren barruan gertatu dela euren hizkuntzaren garapena. Haatik, jatorrizko ingurunetik kanpo bizi izan direnek, demagun ingurune erdaldun batean, hizkuntza etxeko funtzioetara zokoratuta garatu dute eta eskolan eta lagunartean beste barietateren bat erabiltzen dute eskuarki. Hau guztia gogotan jatorrizko hizkuntzatzat euskara eduki dutenen artean hiru multzo nagusi egin ditzakegu (A1, A2 eta A3):

Al Barietate klasikoa jaso dutenak, barietate horren ingurunean 
A2 Barietate klasiko jaso dutenak, barietate horren ingurunetik kanpo

A3 Barietate berria jaso dutenak

Jatorrizko hizkuntza gaztelania eduki dutenen artean badirudi halaber, multzo bi bederen egin behar ditugula. Batetik, ingurune erdaldunagoetan bizi izateagatik edo euskara eskolako esparru formal hutsetarako utzi dutelako lekuko batzuek, D ereduetan ikasi izanagatik ere, oso egoera zehatzetan baino ez dute erabiltzen euskara (B1). Bestetik, ingurune euskaldunetan bizi direnak ditugu; hauek, nahi izanez gero, egoera gehiagotan erabil dezakete euskara eta bertako euskaldunen ezaugarriak eurekandu egiten dituzte kasu askotan (B2).

Jatorriari legozkiokeen goiko faktoreez gain, bariazioaren eragiletan garrantzitsuenak hiru direla esan dezakegu: Euskara Batuaren ezarpena; Erdaren presioa eta Euskararen irakaskuntza.

Euskara batuaren ezarpena ezinbestekoa izan da hizkuntzaren iraupenerako eta hizkuntzaren normalizazioan. Euskara batuaren egonkortze prozesuan gehiegikeria batzuk egin diren arren (honetarako ikusi adibidez Zuazo, 2000, 2003, 2005), ezin ukatuzkoak dira beronen onurak. Hala ere, euskara batuak ahozko barietate berriak eragin ditu oso urte gutxiko epean. Euskara batua idazteko moldetzat baino ez zen ikusten sortu zenean. Gaur egun esparru publiko gehienetan, hau da, irakaskuntzan, hedabideetan eta hizkuntzaren teknologietan, bera baino ez da erabiltzen. Are gehiago, esparru pribatuetan ere sartu da euskara batua, edo hobeto esateko, euskara batuan oinarritutako barietate berriak, gainera familia barruan transmititzen da lehen hizkuntza gisa. Argi dago euren barietate linguistikoen ezaugarriak ere ikertu behar direna eta gogotan erabili behar direna.

Erdara da aldaketen eragile garrantzitsua ere; Hegoaldean gazteleraren presioa eta Iparraldean frantsesarena oso handia da eta beronek eragin ditu aldaketa batzuk eta eragiten ere egiten ditu.

Euskararen irakaskuntzaz azterketa eta material asko egin da; dena den, irakasten den ahozkoaren gainean ez dago lan askorik gure jakitatean; irakurketa ozenaren gainean egin genuen lan baten esaten genuen bezala (Gaminde eta Goikoetxea, 2005), irakurketa ez lantzeak bat-bateko ahozkoari berari eragiten dio. Berorren ondorioz gaztelaniaren (eta beharbada frantsesaren) arau fonologikoak aplikatu egiten zaizkio bat-batekoari, baita erregistro ez formaletan ere.

Bariazio diafasikoan erregistroak irudika ditzakegu segida batean; bata bestearekin nahasirik agertzen dira mugetan, baina formala eta ez formala argi bereizten dira. Erregistro horiek bana daitezke hizkuntzaren funtzioen arabera, banaketa horren barruan hizkuntz forma batzuek edo besteek euren espazioa edo espazio zehatzak beteko lituzkete. Gure ikerketa honetan bat-bateko testuetan erregistro bi erabiltzen dira: bata lagunartekoa bat-bateko testuan eta bestea jasoagoa ataza gidatuan; testu irakurrian maila jasoa ikertu nahi da, izan ere, testu bera erabiliko da lekuko guztiekin.

\section{Prosodiaz}

Prosodia izenaren azpian definizio asko ediren dezakegu bibliografia errepasatuz gero, hona hemen The Speech Science Research Centre-k ematen duen bat (2007):

In other words, prosody is the suprasegmental aspects of speech including variations in pitch/ fundamental frequency, loudness/intensity, duration, pause/silence, intonation, rate, stress and rhythm.

Ez da gure helburua hemen definiziorik onena bilatzea, izan ere, hain konplexua den esparru batean horrelako beharlekuetan sartuz gero beti daukagu arriskua zer edo zer ahazteko. Horregatik beste definizio bat bilatu beharrean interesgarriago iritzi diogu ahotsaren bidez hizketan islatzen diren informazio motak bertora ekartzeari. Fujisaki-ren arabera (2004) hiztunak hiru informazio 
mota transmititzen ditu hizketaren tasun segmentalen eta suprasegmentalen bidez. Mota horiek linguistikoak, paralinguistikoak eta ez-linguistikoak dira; berak esaten duen moduan, hiru horien arteko mugak beti ez dira argi egoten.

Informazio linguistikoa sinbolo diskretu eta arau multzotzat definitzen du. Informazio paralinguistikotzat intentzioa, jarrera eta hizkera estiloak jotzen ditu; eurok arteragokoen moduan hiztunaren kontrolpean daude. Informazio ez-linguistikoa adina, generoa, izaera, egoera fisikoa eta emozionala moduko faktoreei dagokie; faktoreok ez daude zuzenki lotuta hizkeraren eduki linguistikoekin eta paralinguistikoekin eta hiztunak ez ditu kontrolatzen, nahiz imita ditzakeen. Egileak paralinguistikoen eta ez-linguistikoen mugatu ezintasuna nabarmentzen du bereziki.

\begin{tabular}{|c|c|c|}
\hline Category & Examples & Discrete/Continuous \\
\hline linguistic & $\begin{array}{c}\text { lexical (word, accent, etc.) } \\
\text { syntactic (phrase structure, etc.) } \\
\text { semantic } \\
\text { pragmatic (discourse, focus, etc.) }\end{array}$ & discrete (symbolic) controlled by speaker \\
\hline paralinguistic & $\begin{array}{c}\text { intentional (exhortation, etc.) } \\
\text { attitudinal (politeness, etc.) } \\
\text { stylistic (fast, slow, etc.) }\end{array}$ & $\begin{array}{c}\text { discrete and continuous can be controlled } \\
\text { by speaker }\end{array}$ \\
\hline $\begin{array}{c}\text { non- } \\
\text { linguistic }\end{array}$ & $\begin{array}{c}\text { physical (age, gender, etc.) emotional (joy, } \\
\text { sorrow, etc.) idiosyncratic }\end{array}$ & $\begin{array}{c}\text { discrete and/or continuous generally } \\
\text { cannot be controlled but can be simulated }\end{array}$ \\
\hline
\end{tabular}

2. Taula: Ahotsaren bidez transmititzen diren informazioak.

Funtzio linguistikoak intonazioaren bidez gauzatzen dira bereziki eta enuntziatuen egitura fonologikoarekin zerikusia daukate, hala nola sintaxiaren egiturarekin ere. Honen betekizunetako bat oinarrizko maiztasunaren baranoak osatzen dituzten unitate tonalak (tonuak, oinarrizko maiztasunaren ibiltartea, azken silaben luzapena, e.a.) sailkatzea eta arauak ezartzea da. Bestetik, identifikatu diren unitate tonal horiek txertatzeko unitate prosodikoen mugatzea (intonazio sintagmak edo talde prosodikoak, azentu sintagmak, e,a,) ere bada beste betekizun garrantzitsu bat. Azkenik, kate mintzatuaren antolaketan etenak sailkatzea eta sintaxiarekiko eta fonologiaren gaineko unitateekiko erlazioak zehaztu egin behar ditu.

Funtzio paralinguistikoetan hiru multzo nagusi egin ditzakegu; automatikoak, estilistikoak eta adierazgarriak. Automatikoak dira hiztunak zuzenki kontrolatzen ez dituenak eta eurotan adina, sexua eta egoera fisikoaren berri ematen dituztenak kokatzen dira. Estilistikoak, ostera, hiztunaren kontrolpean daudenak dira; estilistikoetan aldaki sozial, geografiko eta kulturalen berri emateko funtzioak dauzkagu eta, adierazgarrietan, jarrerak eta emozioak daude.

Funtzio linguistikoetan, paralinguistikoetan zein ez-linguistikoetan korrelato akustiko berberak erabiltzen dira. Oinarrizko maiztasuna edo F0 (mailak, ibiltartea, baranoa, mugimendua) iraupena (luzera, kantitatea) energia (zabalera, intentsitatea) ahots mota edo kalitatea (formakinak, ahoskabetzeak, aldaketak).

Euskararen kasuan, dela prosodiaren alde linguistikoan dela alde paralinguistikoan, ikerketak hastapenetan daudela esan behar dugu. Ikerketa batzuk burutu diren arren (ikusi Gaminde eta Goikoetxea 2005, bibliografia zehatzerako), euron helburuak oso desberdinak izan dira.

Metodologiari dagokionez, ikerketa esparru batzuk irudikatzen ahaleginduko gara jarraian. 
Mozziconacci-ri (1998) jarraikirik, uste dugu lehen etapan deskripzio akustikoak egin behar direla, deskripzio akustiko horietan lortzen diren parametroak pertzepzioaren bidez balioetsi behar dira eta aldi berean lortzen diren emaitza ziurrekin materialak sortu behar direla. Prosodiaren alde guztiak landu behar dira batera: linguistikoa, paralinguistikoa eta ez-linguistikoa. Ondoko eskeman kontuan hartu behar direnak adierazten ditugu

\begin{tabular}{|l|l|}
\hline Izari akustikoak & F0, iraupena, energia, ahots kalitatea \\
\hline Funtzioak & $\begin{array}{l}\text { Linguistikoak } \\
\text { Paralinguistikoak } \\
\text { Ez-linguistikoak }\end{array}$ \\
\hline Ikuspuntua & $\begin{array}{l}\text { Produkzioa } \\
\text { Pertzepzioa }\end{array}$ \\
\hline Bariazioa & $\begin{array}{l}\text { Bariazio geografikoa } \\
\text { Bariazio soziala } \\
\text { Bariazio estilistiko kulturala }\end{array}$ \\
\hline Erabilera esparruak & \begin{tabular}{l} 
Komunikabideak, kaleko erabilerak, erabilera akademikoak, e.a. \\
\hline Hizkera mota
\end{tabular} \\
\hline Testu motak & $\begin{array}{l}\text { Bat-batekoa } \\
\text { Irakurria }\end{array}$ \\
\hline
\end{tabular}

3. Taula: Deskripzio akustikoetan kontuan hartu behar diren faktoreak.

Marko teoriko honen barruan gure proiektuan aukeratu ditugun ikergai bakoitzeko lortu nahi diren helburuak eta zergatiak azalduko ditugu.

\subsection{Azentua}

Orain arte egin diren lan guztietan agerian jartzen izan da azentua eta intonazioaren arteko lotura (Elordieta eta Hualde, 2001 eta 2003, Hualde, 2003a, Hualde eta lag., 2002, Elordieta, 1999, 2000, 2003, 2006, 2007a eta b), izan ere, azentudun silaban edo beronen inguruan gertatzen dira tonu mugimendurik nabarmenenak. Hori dela eta, euskararen kasuan behintzat, azentu sistemak ikertzea eta arau nagusiak finkatzea ezinbesteko bihurtzen da intonazio ereduak ikertzeko unean. Azentu sistemen ikerketen egoeraz Hualde (2006) eta Elordietaren (2008) artikulu dokumentatuetara jo daiteke, hemen ideia orokor batzuk baino ez ditugu azalduko.

Ikerketa sakonik ezin egin dezakegu proiektu honen mugen barruan; hala ere, azentuaren gainean burutuko ditugun inkestek, lekukoen azentu eredua deskribatzeko baino, intonazioa, emozioak eta jarreran lantzeko jasoko ditugun esaldien berben azentuen kokagunea finkatzeko balioko digute. Berba bakartuen bidez berba bakoitzaren silaba azentuduna zein den jaso dezakegu eta «da» atzizki klitikoaren bidez egineko grabazioetan zehaztu ahal izango dugu zein den azentueraren eremua neurri baten.

\subsection{Intonazioa}

Intonazioaren azterketan hiru azpi-atal aztertuko ditugu: esaldi enuntziatiboak, bai/ez galderak eta $\mathrm{n} / \mathrm{z}$ galderak.

Esaldi enuntziatiboen azterketan hiru esaldi mota baino ez ditugu landuko. Kasu guztietan ahaleginduko gara fokalizatutako sintagma ez izateko aditza bera, izan ere, jakina den moduan, barietate batzuetan behintzat, intonazioaren bidez fokaliza daitezke aditza bera edo beronen aurreko sintagma (1. eta 2. irudiak). 


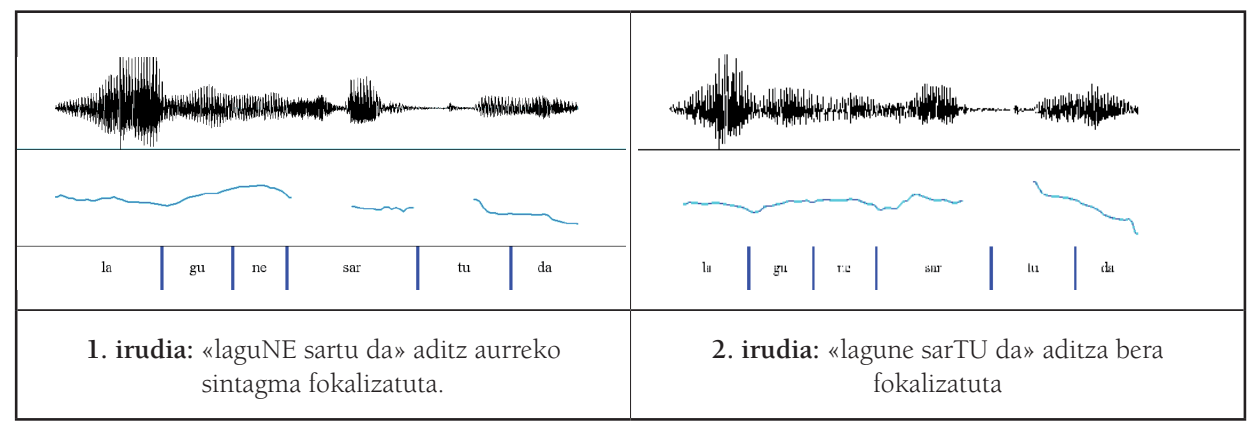

Aukeratu ditugun esaldietan aditzaren aurrean sintagma bakar bat egongo da, berori bakuna edo konplexua dela, eta sintagma bakun bi. Sintagma bakunak eta aditza hiru silabakoak dira, eta konplexua bost silabakoa. Hemen sortzen den arazo metodologiko bat hitz berberak silaba kopuru berberekin barietate guztietan erabiltzea izaten da. Laburtzapen baten ondorioz barietate batzuetan hiru silabakoak diren berbak beste baten silaba bikoak izan daitezke. Era berean hitz batzuk ez dira leku guztietan erabiltzen. Gure kasuan arazo honi aurre egiteko silaba kopuruari eustea erabaki dugu; orduan, lekuko guztiek silaba kopuru eta sintagma kopuru berberak erabiliko dituzte, hitzak barietateen arabera egokitu behar ditugun arren.

Euskararen barietateetan galderak egiteko molde nagusi bi dauzkagu; barietate batzuetan esaldi enuntziatiboak eta galderazkoak tonuaren bidez baino ez dira bereizten (3. eta 4. irudiak).

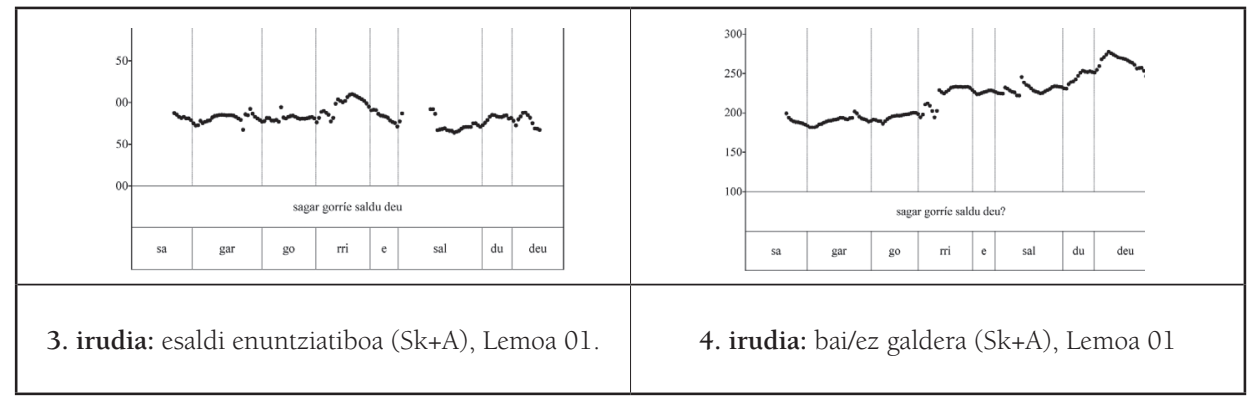

Honelako kasuetan, orain arte dakigunaren arabera mota nagusi bi erabiltzen dira. Eredu batean batzuetan $\mathrm{H}^{*}+\mathrm{L} \%$ tonua txertatzen da amaieran eta beste batzuetan $\mathrm{H} \%$; desberdintasunak 5 . eta 6. irudietan ikus daitezke.

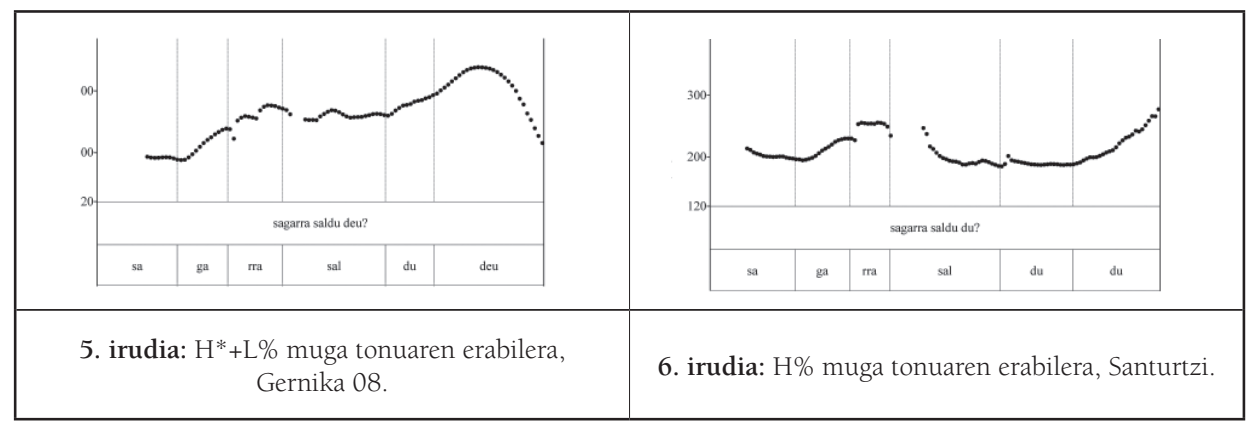


$\mathrm{H}^{*}+\mathrm{L} \%$ erabiltzen duten lekukoek egiten duten beste desberdintasun bat $\mathrm{H}^{*}$ kokatzeko silaba da; batzuek azken silaban kokatzen dute eta beste batzuek, ostera, azkenaurrekoan.

N/Z galderak, bai/ez galderen aldean, galdetzaile baten bidez egiten direnak dira. Gure asmoa atal honetan lekukoen artean dauden joerak deskribatzea da. Alde batetik galdetzailean gertatzen dena aztertuko dugu eta bestetik azken tonuarekin. Esaldien azken tonuari dagokionez, aldaketa nabarmen bat sumatu dugu aspaldion; eta 7. eta 8. irudietan ikusten den bezala lekuko nagusiak L\% muga-tonua erabiltzen du eta lekuko gazteak $\mathrm{H} \%$; datu hauek guztiz bat datoz Bizkain jaso genituenekin (Gaminde, 2008).

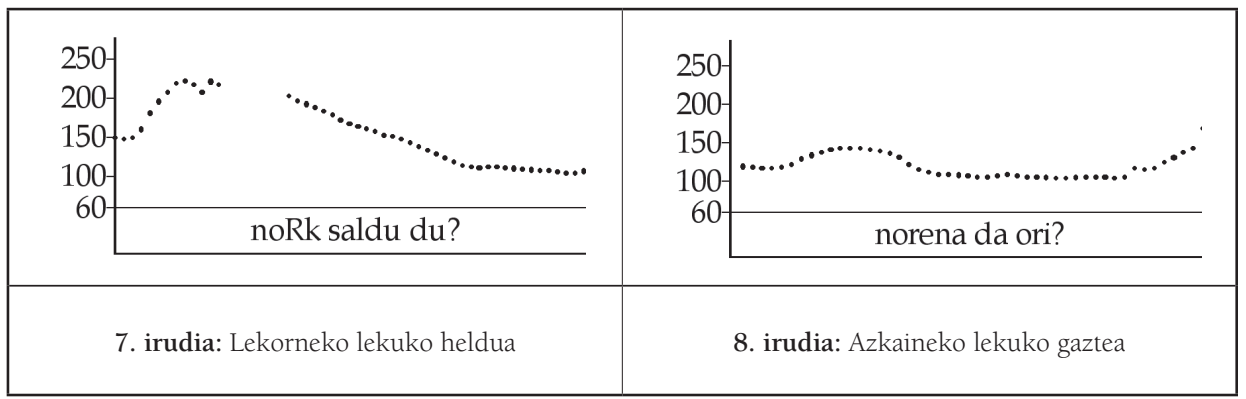

\subsection{Emozioak}

Emozioa adieraztea guztiz lotuta dago gizakion izaerarekin eguneroko bizimoduan. Hala ere, arakatu ahal izan dugun bibliografian hizkera emozionala esan diezaiokegunaz hori da adostuta dagoen puntu bakarra, izan ere, esparru honetako arlo guztiak nahikoa eztabaidagarriak dira. Emozioa bera zer den anbiguo agertzen da, ez dago definizio bakar bat, are gehiago egin diren bibliografia arakaketetan ehun bat definizio agertzen dira (Liscombe, 2007).

Antzera gertatzen da emozioen sailkapenari dagokionez; egile batzuek bi mailatako emozioak bereizten dituzte, oinarrizkoak eta bigarren mailakoak (ikusi Gustafson-Capková 2001). Beste batzuek ostera emozioak eta jarrerak ez dituzte bereizten. Badirudi Fawzy El Sayed-i (2007) jarraikirik cuntinuum baten aurrean gaudela. Emozioen sailkapenaren gainean bibliografian denetarik topatu dugun arren; taulan ikusten den moduan, badirudi emozio batzuk nahikoa arruntak direla egin diren sailkapen guztietan, hala poza, tristura eta haserrea; beste batzuk, ostera, ez dira hain orokorrak.

\begin{tabular}{|c|l|l|}
\hline Hizkuntza & \multicolumn{1}{|c|}{ Egileak } & \multicolumn{1}{|c|}{ Emozioak } \\
\hline Errusiera & Makarova eta Petrushin, 2003 & $\begin{array}{l}\text { poza, tristura, haserre, beldurra eta } \\
\text { harridura }\end{array}$ \\
\hline Finesera & $\begin{array}{l}\text { Seppänen, Toivanen, eta Väyrynen, } \\
2003\end{array}$ & $\begin{array}{l}\text { poza, tristura, beldurra, higuina, asperdura, } \\
\text { haserre handia }\end{array}$ \\
\hline Punjabi & Dawood, Shahid eta Ahmed, 2004 & poza, tristura eta haserrea \\
\hline Thai & Tumtavitikul eta Thitikannara, 2006 & poza tristura, haserre eta harridura \\
\hline Turkiera & Mesut Meral eta lag., 2002 & poza, tristura eta haserre \\
\hline Txinera & Gandour eta lag. 2003 & poza, tristura eta haserrea \\
\hline
\end{tabular}

4. Taula: Emozioen sailkapenak hizkuntza batzuetan. 
Emozioak eta egoera emozionalak definitzea eta sailkatzea zaila izanagatik ere, gai honen inguruko ikerketak ugalduz doaz etengabe, ikuspuntu desberdinez eginak gainera. Egia esanda, teknologian aplikatzeko egin direnak dira ugarienak, baita gure artean ere, ikustea besterik ez dago AHOLAB taldeak egineko lanak (Sainz eta lag., 2008, Navas eta lag., 2004, 2005, 2007, Saratxaga eta lag., 2006, askoren artean).

Gure aurreko lanean egin genuen moduan azterketa fonologikoa eta fonetikoa batera egitea proposatzen dugu. Lehenengoan ikusi behar da txertatzen diren azentu tonudunak emozioen arabera beti batzuk diren ala ez, izan ere, lekuko batzuek gailur prosodikoa aditz aurreko silaba azentudunean kokatzen dute emozio guztietan, beste batzuek ondoko silaban eta beste batzuek silaba batean edo bestean emozioen arabera (9., 10. eta 11. irudiak). Bigarrenean, azterketa akustikoaren ondoko izariak aztertuko ditugu: f0ren batezbestekoa, f0ren ibiltartea (fo ib), energiaren batezbestekoa (db) eta esaldiaren luzera (ms)
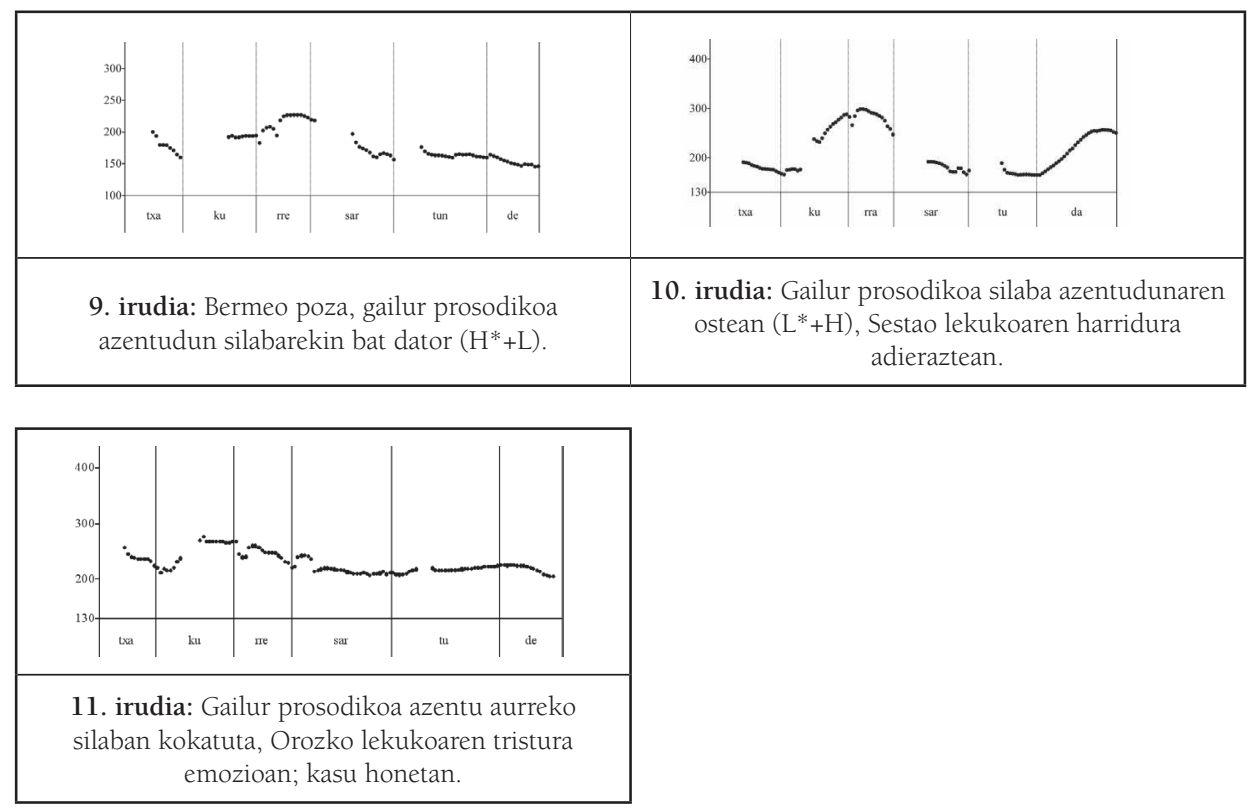

\subsection{Jarrerak}

Jarrerak aztertzeko eurok emozioen aldean zertan bereizten ditugun adierazi behar dugu. Bai jarrerak bai emozioak prosodiaren funtzio paralinguistikoen eta ez-linguistikoen eremukotzat jo ditzakegu. Biak erlazionatuta egon daitezkeen arren, ez dugu uste gauza bat direnik, bibliografian sarritan batera agertu arren. Emozioek erabiltzailearen egoeraren berri ematen dute; nahiz eta ezinbestekoa ez den inori berri horren ematea, gerta daiteke mintzatzaileak ezin kontrolatzea emozioaren adierazpidea. Jarreren kasuan, aldiz, mintzatzaileak adierazpidea kontrolatu eta adierazi nahi izaten dio beren-beregi beste inori, hots, mintzatzailearen eta entzulearen arteko interakzioa egon behar da derrigor. Mintzakideen arteko interakzio hori hain zuzen da bereizgarri nagusia (Wichmann, 2002, bibliografiaren eztabaidarako Al-Sibai, 2004, ikus daiteke)

Emozioak adierazteko erabiltzen diren adierazle akustiko berberak erabiltzen dira jarrerak adierazteko. Era berean, euron arteko erlazioa egon daitekeena ezin ukatuzkoa da; nolabaiteko 
korrelazio positiboa egin daiteke pozaren eta jarrera ironikoaren artean, tristuraren eta jarrera abegikorraren artean eta haserrea eta jarrera errietariaren artean. Hiru hauek izango dira gure proiektuan landuko ditugunak.

Jarreretan, emozioetan bezala, azterketa akustikoarekin batera, azterketa fonologikoa ere egin behar da, hau da, silaba azentudunaren inguruan txertatzen diren tonuak jarreren arabera aldatzen diren ala ez ikusi behar da. 12. 13. eta 14. irudietan ikus daitekeen bezala lekukoak jarreren arabera gailur prosodikoa silaba desberdinetan kokatzen du.
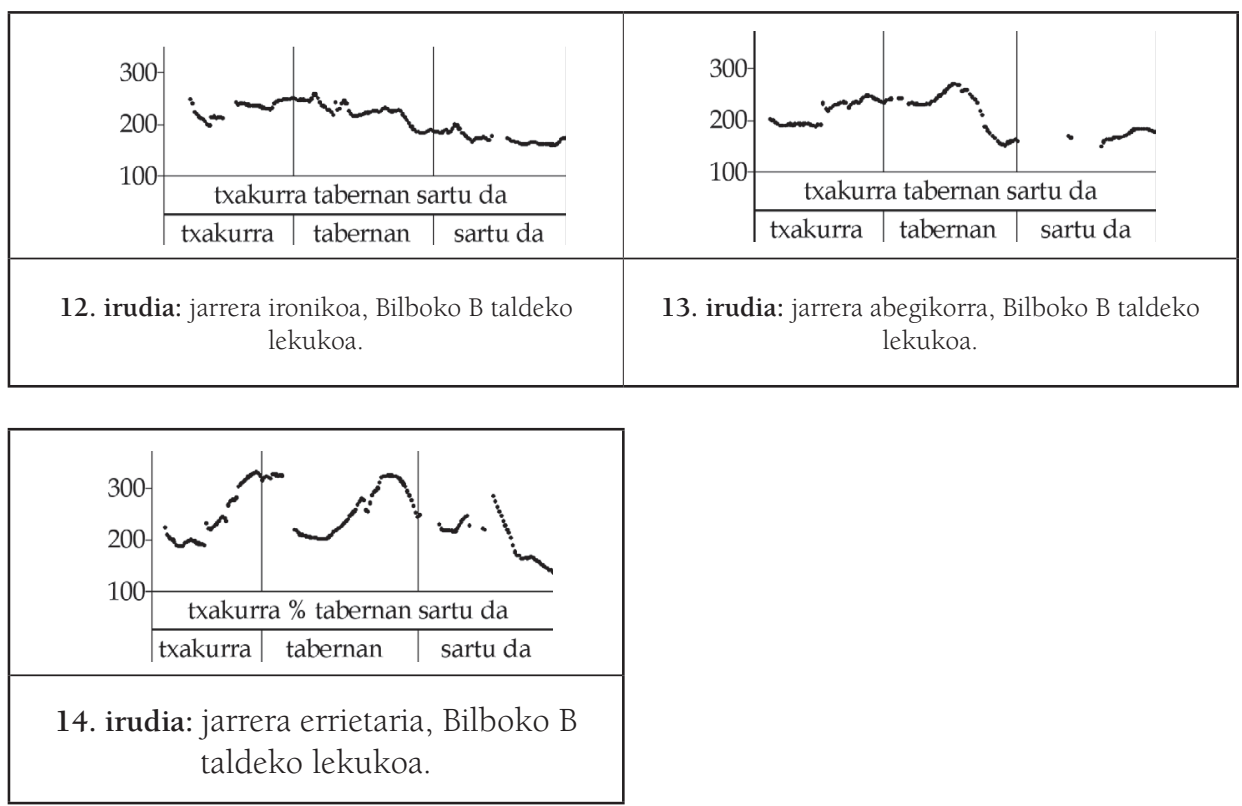

Gure artean eta gugandik aparte testu osoen prosodiaren gainean egin diren lan apurretan, ikerketa mota honen garrantzia nahikoa nabarmendu da berriki, izan ere, laborategiko hizketaren aldean hainbat urruntze kausitu dira emaitzetan (Face, 2003, Rao, 2006, e.a.). Topatu diren desberdintasunetan bat izan da L\% muga-tonuaren agerpen urritasuna bat-bateko testuetan (Rao, 2006). Honi eransten badizkiogu, euskara batuaren azentuan eta intonazioan Gaminderen (2008) lanean aurkeztu ziren aldeak, argi dago bat-bateko testuak eta testu irakurriak bereiz aztertu behar direna.

Hiru testu mota jasoko ditugu. Bat-bateko narrazioa, bat-bateko testu gidatua eta testu irakurria. Lehen testua jasotzeko lekukoek lagunarteko edo etxeko erregistroa erabili beharko dute eta istorio mutu baten bidez islatzen den narrazioa eraiki behar dute. Instrukzioa jasotzeko task map deritzon teknikan oinarritzen da; lekukoei eskatzen zaie mapa baten puntu batetik beste batera informazioa eskatu duen turistari instrukzioak emateko. Mapan eraikinen izenak agertzen dira euskara batuan, lekuko guztiek molde berberak ikusiko dituzte. Kasu honetan testua ez da guztiz askea eta erregistroa jasoa edo beronetatik hurbil dabilena erabiliko dutelakoan gaude. Azkena testu irakurria burutzeko albiste bat irakurri behar dute euskara batuan idatzita, lekuko guztiek albiste bera irakurriko dute.

Honelako testuen bidez, azter daitezkeenak besteak beste etenak, muga-tonuak, talde proso- 
dikoen luzera, hizkera erritmoa eta artikulazio erritmoa dira.

Aurreko behar batzuetan ikusi dugun moduan (Gaminde 2004, 2006), etenak isilune baten bidez egin daitezke edo isilunea egin barik. Horren arabera batzuk isilunedunak izango dira (\%) eta beste batzuk hain bakoak (\$). Zenbaitetan, kurba zatien arteko loturak egiteko edo pentsatzeko denbora hartzeko bokalak luzatu edo txertatu egiten dira isilunearen aurrean. Luzapenaren kasuan, luzatzen den bokala hainbat luzeagoa izaten da arrunten batezbestekoaren aldean. Txertaketa edo luzaketa hauek aurrekoekin konbinatuta lau aukera gertatzen dira:
(a) + Isilunedun etenak/- bokal txertaketa (\%) (6.1.)
(b) + Isilunedun etenak/+ bokal txertaketa (v\%) (6.2.)
(c) -Isilunedun etenak/ - bokal txertaketa $(\$)(6.3 .)^{1}$
(d) - Isilunedun etenak/ + bokal txertaketa (v\$) (6.4.)

Eredu metriko autosegmentalean egin diren ikerketa gehienetan muga-tonu bi baino ez dira proposatu L\% eta H\%. Tonu ertaina (M\%) aurreko bien konbinaziotzat jotzen da; gure kasuan, testuen azterketa egitean, beharrezkotzat jo dugu M\% muga-tonua erabiltzea aurreko tonuari eusten zaionean. Eten baten ondoan dauden fo mugimenduak hiru motatakoak dira goranzkoak, beheranzkoak eta lauak edo aurrekoari eusten diotenak. Behar fonetiko batzuetan azken honi jarraipen tonala esaten izan zaio (Aguilar, Casacuberta, eta Marín, 2000).

$\mathrm{H} \%$ muga-tonua testuetan maiztasunik handiena daukana da, edozein eten motatan agertzen da. H\%ren igoera aurreko silaban edo silabetan has daiteke eta baita azken silaban edo bera kokatuta dagoen silaba berean (15., 16. eta 17. irudiak).
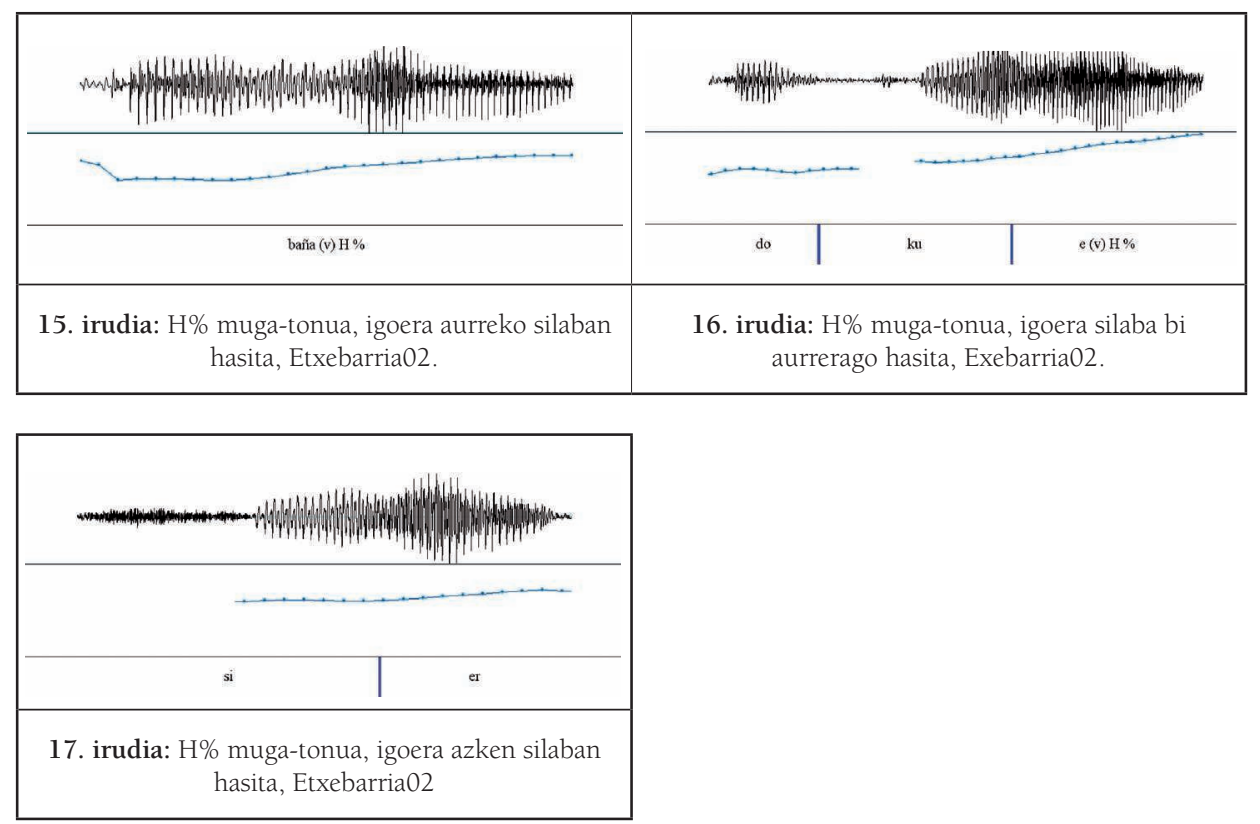

1. Kasu honetan etenaren efektua kurbaren aldaketa bortitz batek eragiten du. 
Talde prosodikotzat hartuko dugu etenen artean dagoen hizketa zatia. Berorren arabera euron luzera aztertuko dugu. Talde prosodikoaren luzera, etenak eta etenetan gertatzen diren muga-tonuak hizketa erritmoarekin lotzen dira. Erritmoa hizkuntzaren tasun bereizgarritzat jotzen da (Canepari, 2007):

«Ogni lingua ha un suo ritmo particolare, che deriva dalla structura delle sillabe e dei gruppi ritmici, o ritmie. (223)»

Hizkera erritmoa eta artikulazio erritmoa denbora unitateko egiten den silaba edo soinu kopuruarekin lotuta dago. Lehenengoan etenen denbora kontuan hartzen da eta bigarrenean denbora osoari etenen denbora kendu egiten zaio.

Lan honen bidez gutako baten (Gaminde, 2008) lanaren amaieran egiten ziren galderei erantzun nahi zaie; era berean, han iradokitzen ziren sakontzeko bide batzuei oratu nahi izan zaie. Geroak esango du, bego oraingoz hemen, gero dioenak oraingoan bego ez dioela.

\section{Bibliografia}

Aguilar, L.; Casacuberta, D. eta Marín, R., 2000, «Labeling Melodic Movements at the Stress Group Level» CatWPL 8.

Al-Sibai, D. M., 2004, Intonation: A Suprasegmental Aspect of the English Language. http://docs.ksu. edu.sa/PDF/Articles51/Article510051.pdf

Aurrekoetxea, G., 2003, "Euskalkiak estandarraren uholdepean (Arratiako kasua)", in Ahozkotasuna Aztergai, Mendebalde Kultur Elkartea, Bilbo, 167-178

Aurrekoetxea, G., 2004, "Estandar eta dialektoen arteko bateratze-joerak (ikuspuntu teorikotik begirada bat)" Uztaro 50, 45-57.

Aurrekoetxea, G., 2006, "Hizkuntza estandarraren eta dialektoen arteko bateratze joerak" in J. Lakarra eta J. I. Hualde (arg.), Studies in Basque and Historica Linguistics in Memory of R. L. Transk. R. L. Trasken oroitzapenetan ikerketak euskalaritza eta hizkuntzalaritza historikoaz, ASJU XL: 1-2, 133-160.

Aurrekoetxea, G., 2008, "Bariazio soziolinguistikoa Dimako euskaran” Euskalingua-12, 17-26

Aurrekoetxea, G. eta J. L. Ormaetxea, 2006, "Euskararen Atlas Sozio-Geolinguistikoa" ikerketa proiektua", Euskalingua 9, 157-163

Canepari, L., 2007, Fonetica e Tonetica Naturali: Approccio articolatorio, uditivo e funzionale. Lincom Textbooks in Linguistics.

Dawood, H.; Shahid, R., Ahmed, T., 2004, "Intonation Patterns in Punjabi" http://www.crulp.org/ Publication/Crulp_report/CR04_05E.pdf

Elordieta. G., 1999, Primer estudio comparativo de la entonación de tres variedades dialectales vascas, Actas del I Congreso de Fonética Experimental, Universitat Rovira i Virgili y Universitat de Barcelona, 209-215.

Elordieta. G., 2000, "Mendebaldeko intonazioaren inguruan", in Mendebalde Kultur Alkartea: Mendebaldeko berbetearen formalizazinoa. Bilbo, 111-136.

Elordieta. G., 2003, "Intonation", in J.I. Hualde eta J. Ortiz de Urbina (arg.), A grammar of Basque, Mouton de Gruyter, Berlin, 72-112.

Elordieta. G., 2006, "Spanish pitch accent alignment by Northern Bizkaian Basque speakers", in B. Fernandez eta I. Laka (arg.), Andolin Gogoan. Essays in Honour of Profesor Eguzkitza, Bilbo, EHU, 269-290.

Elordieta. G., 2007a, Constraints on intonational prominence of focalized constituents, in D. 
Büring. M. Gordon eta C.L. Lee (arg.), Topic and focus: Papers from a workshop on intonation and meaning. Springer, Dordrecht, 1-22.

Elordieta. G., 2007b, "A constraint-based analysis of the intonational realization of focus in Northern Bizkaian Basque”, in T. Riad eta C. Gussenhoven (arg.), Tones and Tunes: Volume I, Typological Studies in Word and Sentence Prosody, Mouton de Gruyter, Berlin, 201-234.

Elordieta, G., 2008, "Euskal azentu eta intonazioari buruzko ikerketa: status quaestionis" (agertzeko)

Elordieta. G., eta J.I. Hualde, 2001, "The role of duration as a correlate of accent in Lekeitio Basque", in Proceedings of Eurospeech 2001 Scandinavia, CPK, Aalborg University, Aalborg, 115-118.

Enbe, C. eta Tobin, Y., 2008, "Sociolinguistic Variation in the Prosody of Buenos Aires Spanish According to the Theory of Phonology as Human Behavior" in Colantoni, L. eta Steele, J. Selected Proceedings of the 3rd Conference on Laboratory Approaches to Spanish Phonology. Somerville, MA: Cascadilla Proceedings Project.

EUDIA, 2008, Euskara Dialektalaren Ahozko Korpusa. http://sites.google.com/ site/edakeudia/ Home

Face, T., 2003, "Intonation in Spanish declaratives: differences between lab speech and spontaneous speech" Catalan Journal of Linguistics 2

Fawzy El Sayed, N., 2007, "Emotion Recognition from Speech" Information Technology - Dialog Systems University of Ulm

Fujisaki, H. (2004) "Information, Prosody, and Modeling", Proceedings of Speech Prosody, Nara, Japonia

Gaminde, I., 2004, "Tonuak eta etenak Gatikako intonazioan”, FLV 97, 519-536.

Gaminde, I., 2006, "Intonazio kurben etenez", in J. Lakarra eta J. I. Hualde (arg.), Studies in Basque and Historica Linguistics in Memory of R. L. Transk. R. L. Trasken oroitzapenetan ikerketak euskalaritza eta hizkuntzalaritza historikoaz, ASJU XL: 1-2, 351-376.

Gaminde, I. eta Goikoetxea, U. (arg.), 2005, Irakurketa Ozena ebaluatzeko irizpideak Bizkaian. Mendebalde Kultura Alkartea, Bilbo

Gaminde, I., 2008, Bizkaiko Gazteen Prosodiaz: Euskaraz eta Gaztelaniaz. (Agertzeko) Mendebalde Kultura Alkartean

Gandour, J; Wong, D.; Dzemidzic, M. Lowe, M.; Tong, Y eta Li, X., 2003, “A Cross-Linguistic fMRI Study of Perception of Intonation and Emotion in Chinese" Human Brain Mapping 18: 149157

Gustafson-Capková, S., 2001, "Emotions in Speech: Tagset and Acoustic Correlates." Speech Technology, term paper, 1-13

Hualde, J. I., 2003a, "El modelo métrico y autosegmental" in Prieto, Pilar (coor) Teorías de la Entonación. Ariel Lingüistica, Bartzelona

Hualde, J. I., 2004, "Analogy and other types of non-phonetic change in Bizkaian Basque" in J. Lakarra eta J. I. Hualde (arg.), Studies in Basque and Historica Linguistics in Memory of R. L. Transk. R. L. Trasken oroitzapenetan ikerketak euskalaritza eta hizkuntzalaritza historikoaz, ASJU XL: 1-2

Hualde, J. I., 2006, "Estado actual de las investigaciones sobre la acentuación en lengua vasca", Oihenart 21, 149-177.

Hualde, J. I., Elordieta, G, Gaminde, I. eta Smiljanic, R., 2002, "From pitch-accent to stress-accent in Basque", in C. Gussenhoven eta N. Warner (arg.), Laboratory Phonology VII, Mouton de Gruyter, Berlin, 547-584.

Hualde, J. I. ; Lujanbio, O. eta Torreira, F., 2008, "Lexical tone and stress in Goizueta Basque" Jour- 
nal of the International Phonetic Association, 38/1

Liscombe, J., 2007, Prosody and Speaker State: Paralinguistics, Pragmatics, and Proficiency. Doktorego Tesia, Columbia University

Makarova, V. eta Petrushin, V. A., 2003, "Phonetics of Emotion in Russian Speech" Meikai University, AIST, Japan/ Accenture Technology Labs, Accenture, Chicago

Martín Butragueño, P., 2002, "El Estudio de la Entonación del Español de México" http://lef.colmex. $\mathrm{mx} /$ Sociolinguistica/

Mesut Meral, Hazım K. Ekenel, A. Sumru Özsoy, 2002, "Role of Intonation Patterns in Coveying Emotion in Speech" Boaziçi Üniversitesi, in Proceedings of 17th NationalConference on Turkish Linguistics.

Mozziconacci, S., 1998, Speech Variability and Emotion: Production and Perception. Eindhoven: TU, VI, 210 p. Pbck. Proefschrift.

Navas, E, Hernáez, I, Luengo, I, Sánchez, J, 2004, "Análisis acústico de una base de datos de habla emocional" in Sanchis, Emilio, 2004, Terceras Jornadas en tecnología del habla. Valentzia.

Navas, E, I. Hernáez, A. Castelruiz, J. Sánchez eta I. Luengo (2004): "Acoustic Analysis of Emotional Speech in Standard Basque for Emotion Recognition" Lecture Notes on Computer Science 2004-X-28, Springer-Verlag, Berlin

Navas, E.; Inmaculada Hernáez, Iker Luengo, Jon Sánchez, Ibon Saratxaga (2005) "Analysis of the Suitability of Common Corpora for Emotional Speech Modeling in Standard Basque" Lecture Notes on Artificial Intelligence, Vol. 3658, pp.265-272, Sept. 2005

Navas, E; Hernáez, I.; Luengo, I.; Sainz, I; Saratxaga, I. eta Sanchez, J., 2007, "Meaningful Parameters in Emotion Characterisation" Lecture Notes on Computer Science, vol 4775

Rao, R., 2006, "On Intonation's Relationship with Pragmatic Meaning in Spanish" Selected Proceedings of the 8th Hispanic Linguistics Symposium, ed. Timothy L. Face and Carol A. Klee, 103115. Somerville, MA: Cascadilla Proceedings Project.

Sainz, I., Saratxaga, I., Navas, E., Hernáez, I., Sanchez, J., Luengo, I., Odriozola, I. (2008) "Subjective Evaluation of an Emotional Speech Database for Basque" Proc. of the Sixth International Language Resources and Evaluation (LREC'08), paper 437

Saratxaga I, Navas E., Hernaez I., Luengo I., 2006, "Designing and Recording an Emotional Speech Database for Corpus Based Synthesis in Basque" Proceedings of the LREC 2006

Seppänen, T.; Toivanen, J. eta Väyrynen, E., 2003, "MediaTeam Speech Corpus: a first large Finnish emotional speech database" http://www.mediateam.oulu.fi/publications/pdf/

The Speech Science Research Centre "2007, "Prosody and Autism Spectrum Disorders" Queen Margaret University. http://www.qmu.ac.uk/ssrc/prosodyinasd/

Tumtavitikul, A. eta Thitikannara, K., 2006, "The Intonation of Thai emotional speech" in Warren, P. eta Watson, C: Proceedings of the 11th Australian International Conference on Speech Science $\&$ Technology, University of Auckland, New Zealand.

Uranga, B.; Aierdi, X.; Idiazabal, I.; Amorrortu, E.; Barreña, A. eta Ortega, A., 2008, Hizkuntzak eta Immigrazioa. Ikuspegi eta Amarauna Unesco Etxea. Bilbo.

Wichmann, A., 2002, "Attitudinal Intonation and the Inferential Process" in: Bel, B., Marlien, I. (arg.), Proceedings of the Speech Prosody Conference.11-16.

Zuazo, K., 2000, Euskararen Sendabedarrak. Alberdania. Irun.

Zuazo, K., 2003, Euskalkiak, Herriaren lekukoak. Elkar. Donostia.

Zuazo, K., 2005, Euskara batua: Ezina ekinez egina. Elkar. Donostia. 